\title{
Migratsioon versus kodu: vaateid ühele uurimisprojektile
}

\begin{abstract}
Maruta Pranka
Teesid: Artiklis tutvustatakse migratsiooniprotsesside uurimise biograafilisi lähenemisvõimalusi, võttes aluseks uurimisprojekti "Māja" (Kodumaja) materjalide analüüsi. Migratsioon kui inimeste liikumine ühest asukohast teise, kaugemasse või lähemasse paika toob kaasa kodu muutumise. Kodumaja on stabiilsuse sümbol, migratsiooni võib iseloomustada selle vastandina.

1995. aastal alustatud uurimisprojektis "Kodumaja" on jätkuvalt töötanud Läti Ülikooli filosoofia ja sotsioloogia instituudi rahvusliku suulise ajaloo projekti uurijad, intervjueerides korduvalt ühe Riia kortermaja elanikke ja tutvudes nende pere- ja koduarhiividega. Uurimuse käigus saadud informatsioon hõlmab ajavahemikku maja valmimisest 1936. aastal kuni tänapäevani. Majaelanike elulugusid käsitletakse uurimuses subjektiivsete sotsiaalsete minevikurekonstruktsioonidena, mida tõlgendatakse vaadeldava maja ja Läti lähiajaloo kontekstis.
\end{abstract}

Märksõnad: biograafiline uurimisviis, eluloouurimine, longituudanalüüs, migratsioon

\section{Sissejuhatus}

Elulood valgustavad enamasti sotsiaalse ja moraalse elu neid aspekte, millest meil on seni olnud vaid kaudsed teadmised, mis on saadud statistikast või ametlikest lugudest. Viimasel juhul oleme need, kes püüavad pimedal ajal maja väljastpoolt vaadates kujutleda, mis majas toimub; elulugude uurimisel aga need, kes avavad ukse ja lähevad sisse. Siis saab nähtavaks see, millest varem oli vaid umbkaudne kujutlus (Robert Park, tsit Hammersley 1990: 74 kaudu).

Linnasotsioloogia Chicago koolkonna silmapaistva esindaja Robert Parki 1929. aastal öeldu väljendab artiklis käsitletava uurimuse olemust ja missiooni. Artikli eesmärk on vaadelda biograafilise uurimisviisi võimalusi migratsiooniprotsesside analüüsil, võttes aluseks projekti "Māja” (Kodumaja) materja- 
lide, sh eluloointervjuude uurimused. Mikrotasandi andmete paigutamiseks üldisse ajaloolisse konteksti on kasutatud statistilisi andmeid.

Uurimisprojektis "Kodumaja" on selle algusest (1996. aastast) töötanud Läti Ülikooli filosoofia ja sotsioloogia instituudi rahvusliku suulise ajaloo projekti liikmed, salvestades Riia ühe korterelamu elanike elulugusid ja tutvudes nende perearhiividega. Uurimisprojekti eesmärk oli visandada Riia ühe maja elanike portreed 1936. aastast tänapäevani. Projekti kestel salvestati kõigi selle maja elanike elulugusid korduvalt. Intervjuud kõnelevad vaadeldava maja loo kõrval ka elust Riias üldiselt. Inimeste elukäigud on uurimuses rekonstrueeritud, seostatuna konkreetse maja ja maja ajalooga. Maja piirab uurimisala, võimaldades elulugude kaudu tundma õppida maja elanikke. Kajastades suhteliselt piiritletud rühma kogemusi, luuakse selle kaudu ettekujutusi väikestest sotsiaalsetest rühmadest. Iga uue või korratud intervjueerimisega on informatsioon täienenud uute faktidega nii tagasivaadetes minevikku kui ka nüüdisaegsete protsesside kajastamisel. Maja ajalugu ja elanike elulugusid käsitletakse intervjueeritavate subjektiivsete ja sotsiaalsete minevikurekonstruktsioonidena, mis uurimisel asetatakse muutuvasse sotsiaal-poliitilisse konteksti. Uurimistöö alguses elas vaadeldavas majas veel suhteliselt palju neid, kes olid seal elanud aastakümneid, üks elanikest (maja omanik) kogu oma elu. See pakkus võimaluse vaadelda majaga seotud inimeste elutrajektoore pikema aja vältel, fikseerides sealjuures üksikisiku elu kujundavad ühiskonnamuutused.

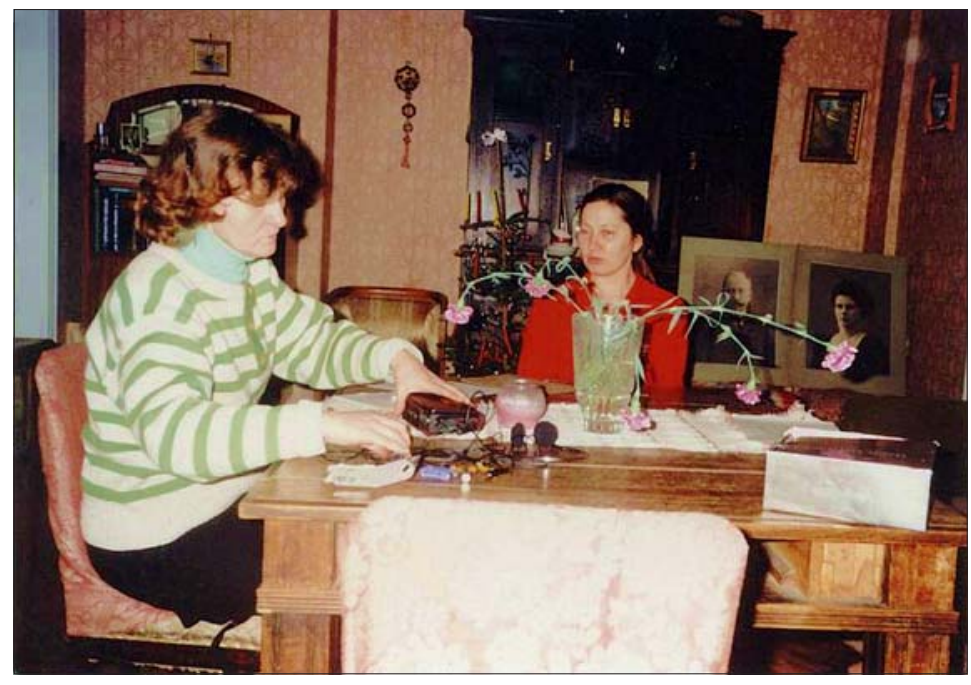

Foto1. Maruta Pranka intervjueerimas majaelanikku, kes jutustab oma esivanematest. Māra Zirnīte foto 1996. 
Projekt pakub hulgaliselt materjali, et uurida erinevaid sotsiaalseid protsesse 20. sajandi Lätis: näiteks migratsiooniprotsesse, sotsiaalsete rollide kujunemise dünaamikat, keskklassi moodustumist, küüditamisi, kohanemist pärast sundasumiselt tagasitulekut. Riigi majanduses ja seadusandluses toimunud muutused on otseselt mõjutanud majaelanike käekäiku, mis peegelduvad ka elulugudes. Neid lugusid kuulates ei tule esile mitte ainult unikaalsed eluloolised teadmised, vaid ilmnevad ka konkreetsete sotsiaalsete rühmade tüüpilised biograafiad, mis juhivad uurijate tähelepanu sellele, kuidas on poliitilised otsused ja ajaloolised sündmused mõjutanud inimeste elu, kuidas on inimeste elukäigud vermitud kindlates sotsiaalsetes kontekstides.

Järgnevas pööratakse tähelepanu sellele, kuidas isikute privaatsed kogemused varieeruvad, sõltudes konkreetsest ajastust. Iga kogemus on iseenesest eriline ja pakub tõlgendusi tõsielu teatud tahkudele, kuid artikkel on üles ehitatud sotsioloogia esmahuvist lähtudes: huvikeskmes ei ole mitte see, mis on toimunud konkreetse isikuga, vaid sündmuste sotsiaalsed kontekstid. Eesmärk on jälgida sotsiaalsete nähtuste ja protsesside arengut, mida võimaldab ühes ja samas sotsiaalses ruumis ja ajas olemasolevate erinevate elukogemuste võrdlemine (vt nt Lauristin 2004: 178). Lähem vaatlus keerleb kahe vastandlikuna käsitletava mõiste ümber: kodu ja migratsioon.

Kodu on eriline väärtus, mis sümboliseerib stabiilsust ja tavasid, varjupaika ja turvalisust. Kodu mõiste kaudu väljendatakse oma identiteeti kõige erinevamatel viisidel - etniliselt, sotsiaalselt, perekondlikult, sooliselt. "Kodu" on rahvusliku identiteedi diskursuse osa, ühtsustunnet loova identiteedi oluline tunnus. See märgib kindlat sotsiaalset territooriumi, kus selle ruumi elanike eraelu saab tegelikuks. Kodu on sotsiaalse praktika võrgustik, mis hõlmab endas teatud käitumisnorme ja väärtusi, luues seost reaalse või konstrueeritud mineviku, kindlate rituaalide või teiste sümboolsete tegevustega. Kodu on meie kultuuri osa, meie vabaduse väljund.

Migratsioon on inimeste mis tahes liikumine ühest asukohast teise, kus läbitakse lühem või pikem tee kas individuaalselt või suuremates rühmades. Migratsioon inimeste liikumisena toob kaasa koduvahetuse. Kui kodumaja on vaadeldavas kontekstis stabiilsuse sümbol, siis migratsioon, olgu vabatahtlik või sunniviisiline, on lahkumine sellest stabiilsusest.

Sotsiaalteadustes räägitakse erinevatest migratsiooniliikidest. Emigratsioon on kodumaalt lahkumine ja elu alustamine teises riigis, immigratsioon - sisseränne teisest riigist. Ahelmigratsioon on mehhanism, mis lubab välismaalastel reisida teise riiki tänu nendele täiskasvanud sugulastele, kes on omandanud vastava riigi kodakondsuse. Sundmigratsioon on isiku või isikute sunniviisiline väljasaatmine nende kodukohast või asualalt. Vaba migratsioon annab isikutele oluliste piiranguteta võimaluse asuda elama mis tahes riiki. Massili- 
ne migratsioon on suurte inimrühmade liikumine ühest geograafilisest piirkonnast teise. Poliitiline migratsioon on peamiselt poliitilistest huvidest tingitud migratsioon. Linnamigratsioon on elanike liikumine maaregioonidest linnadesse. Arvestades Balti riikides 20. sajandil toimunud radikaalseid poliitilisi muutusi on migratsioon kõnesoleva projekti intervjuudes üks domineerivaid teemasid, mida jälgitakse ka selles artiklis.

Elulugude salvestamisel küsiti intervjueeritavatelt sissejuhatuseks andmeid, mis ei sõltu nende tõlgenduslikest valikutest: sünniaeg ja -koht, haridus, vanavanemad ja vanemad, vennad ja õed, perekonnaseis jms. Need andmed moodustavad loo objektiivse raamistiku, pakkudes eluloo analüüsiks üldisemat konteksti.

Uurimisprojekti kese - vaadeldav maja - asub Riia kesklinna ühel vaiksel tänaval ja on ehitatud 20. sajandi kolmekümnendatel aastatel. Esimesed elanikud tulid sinna 1936. aastal. Majas on 19 korterit, kokku 57 tuba. Selles

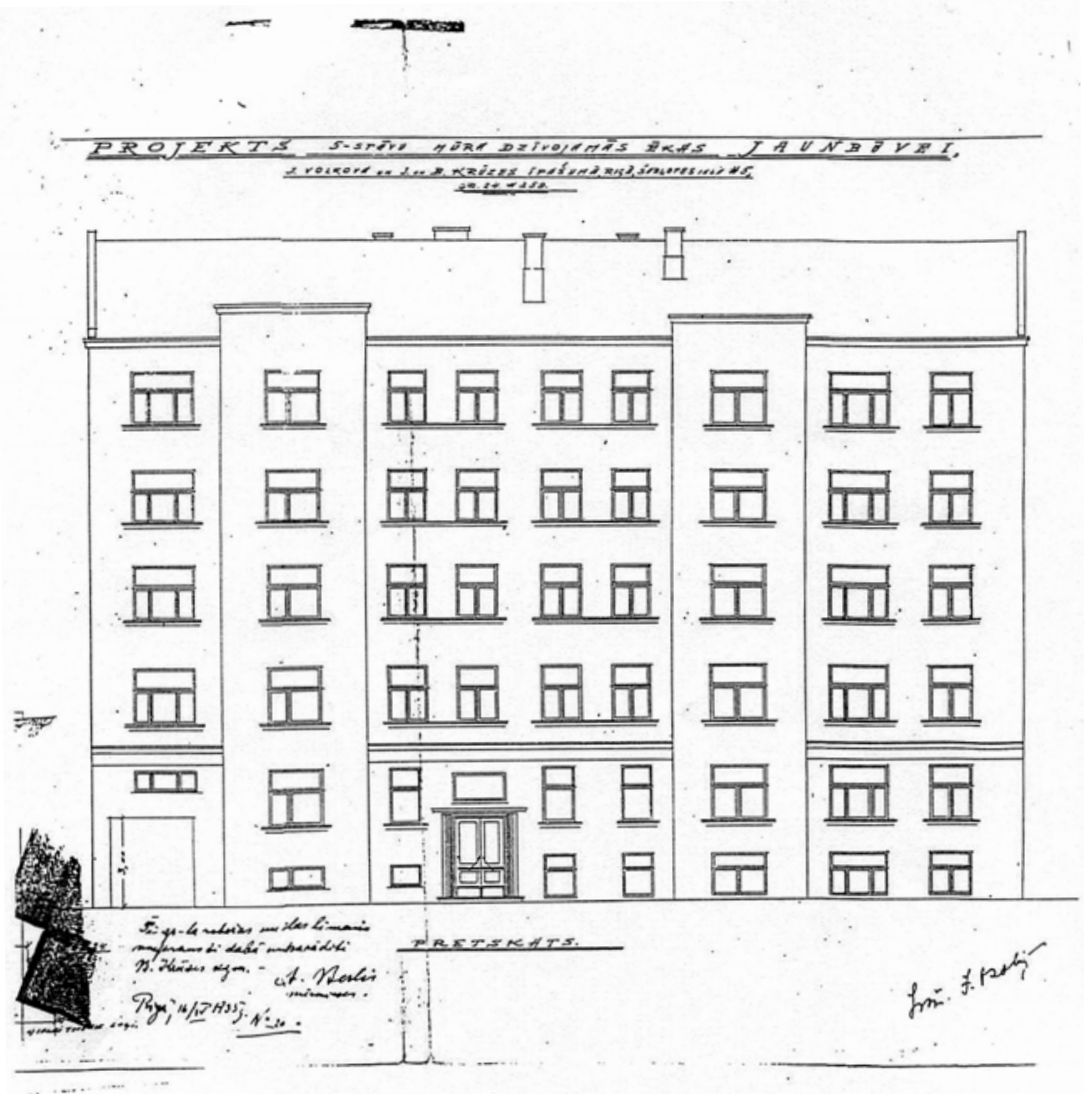

Joonis 1. Maja projekt. Baiba Bela fotokoopia 1997. 
majas on mugav korterite planeering, lai trepikoda, keskküte, ühine prügišaht ja pesumaja keldris. Majja olid kavandatud korterid ka omanikele, samuti ühe advokaadist omaniku kontor eraldi sissepääsuga külastajatele. Nõukogude võimu tulekuga Lätti oktoobris 1940 maja natsionaliseeriti. Pärast Läti taasiseseisvumist 1990. aastal käivitatud tagastamisprotsessi tulemusel said paari aasta jooksul maja omandiõiguse sõjaeelsete omanike otsesed pärijad, nende lapsed. Uurimisprojekti alguseks 1996. aastal elas selles majas kaks perekonda, kelle esindajad olid seal elanud maja valmimisajast peale; kolm peret, kes olid sinna elama asunud enne Teist maailmasõda baltisakslaste repatrieerumise järel (ja selle tulemusena); lisaks mõned pered, kes olid majja tulnud koos Teise maailmasõja võitnud Punaarmeega. Mõne korteri puhul ei olnud üürnike liikumise käik korterite vahetuse tulemusena enam üheselt taastatav. Järgnevas käsitluses lasub raskuskese majaomanike ja nende järglaste lugudel. ${ }^{1}$

\section{Kodumaja: läte ja muutuste algus}

Vaadeldav maja on tüüpiline Riia 20. sajandi kolmekümnendate aastate üürile antavate korteritega elamu. Ka maja omanike elukäik sarnaneb paljude selleaegsete Riia elanike saatustega. Kaks noort juristi ehitavad hüpoteegilaenu abil maja, et nende peredel, kus kasvavad väikesed lapsed, oleks tulevikus kindlustatud alaline elukoht - oma kodu. Omanikud on loonud pere, stabili-

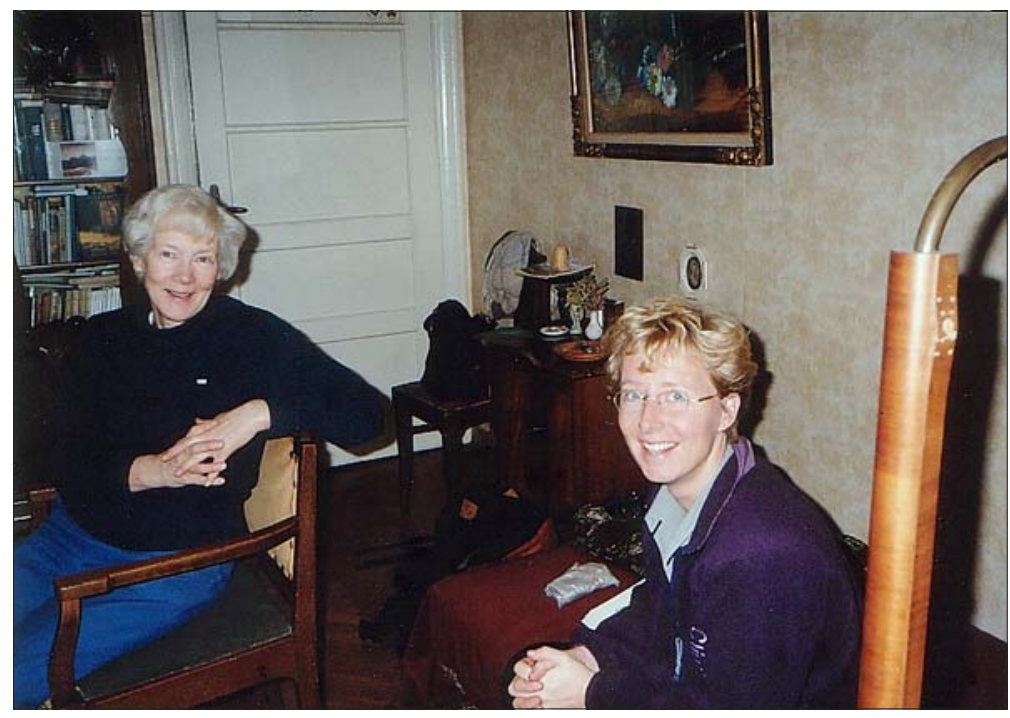

Foto 2. Üks majaomanikke koos külalisega Hollandist. Māra Zirnīte foto 1996. 


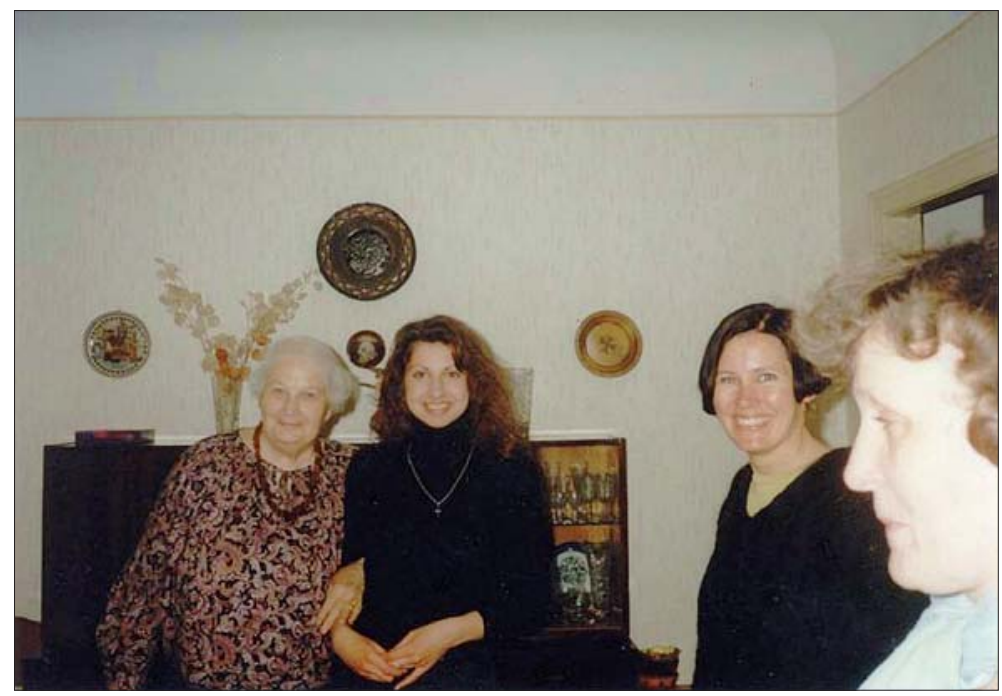

Foto 3. Üks majaomanikke koos lapselapse ja uurimisrühma liikmetega. Māra Zirnīte foto 1996.

seerinud karjääri ja omandanud teatud majandusliku tasakaalu, kuigi majaehitus on toimunud hüpoteegiga tagatud krediidi abil ja on seega seotud teatud rahaliste raskustega, mis intervjueerimisel meenuvad mõlemal maja praegusel omanikul.

Mõlemad jutustajad (maja pärijad ja praegused omanikud) Laima ja Valda on sündinud Riia keskklassi peres. Nende jutustused oma pere ajaloost lubavad esmalt jälgida 20. sajandi alguses maalt linna kulgenud migratsiooni, millega kaasnes linna keskklassi kujunemine. Valda on sündinud 1926. aastal Riias, Laima 1931. aastal samuti Riias. Jutustajate vanemate pered on Riiga tulnud maalt, Vidzeme regioonist. Mõlema jutustaja vanavanemad on teinud rasket tööd, isad on varakult hakanud kandma hoolt oma lähedaste eest, sest vanaisad surid võrdlemisi noorelt. Neis juttudes ei ole kummalgi juhul viidet päritud varale. Mõlema jutustaja isa püüdleb hariduse poole. Ka nende eluteed kulgevad sarnasel viisil.

Ühe jutustaja (Valda) isa tuleb Riiga, kui tema vanaisa on sunnitud 1905. aasta rahutuste päevil mõisnikuga konflikti sattumise tõttu odavalt müüma oma talu ja kolima linna:

Isa on mul sündinud aastal 1891. Kui vanaisa suri, pidi isa hakkama pere eest hoolitsema, talle jäi ema ja kaks õde, temast veidi nooremad. Isa hakkas tööle kirjutajana, aga [19]14. või [19]15. aastal kutsuti ta sõjaväkke ja saadeti praporštšikkude kooli, ja siis Lāčplēsise ordeni sai ta töö 
eest Läti heaks. Ta oli ka õppinud Aleksandri gümnaasiumis ja vaimulikus seminaris. Siis oli ta Poliittalituse uurimisosakonna juhataja. Ta oli see, kes kaitses Lätis rahu. Isal oli suhteliselt hea töötasu. Vabadusvõitluses osalejana oli ta saanud maad kusagil Salduse maakonnas, see maa mü̈̈di maha. Me elasime väga säästlikult. Ja siis ta ehitas seda maja koos Vilcānsiga pooleks, tal olid ka hüpoteegi laenud. Ta võitles kõvasti, et saada maja katuse alla, kuid ta ehitas, et lastel oleks kunagi, kus elada. Ja hiljem sai ta ka kuuli pähe, mitte pähe, vaid selga, ja nü̈̈d lebab Baltezersi kalmistul Stalinismi ohvrite osas.

Teise omaniku (Laima) isa esindab sama põlvkonda ja on pärit samast Läti piirkonnast:

Jah, minu vanaisal oli Vidzemes kaks poega, üks pidi koju jääma ja töötama talus, aga minu isa pidi minema kroonuleiba otsima. Tal olid taskud tühjad, nagu öeldakse, ta pidi leidma sellise kooli, kus ta oli riigi täieliku hoole all. Ja see oli õigeusu vaimulik seminar, kus ta pidi üle minema õigeusku ja muutma perekonnanime venepäraseks. Seal taheti nad pappideks välja õpetada, kes tasapisi venestavad rahva... Aga kahe aasta pärast põgenes ta üle aia... Ja sealt tuli palju juriste, läti poisse, nad nagu said seal veidi haridust ja siis panid plehku. Ja minu isa sõitis Varssavisse, kus ta lõpetas õigusteaduskonna. Siis [Esimese maailma] sõja aastail oli ta üksvahe Koltšaki armees. Siis veel kuskil neil sõja-aastatel oli. Seejärel pärast tagasitulekut oli ta pikka aega vannutatud advokaadi abi tsiviilasjades. Ja siis töötas ringkonnakohtus, hiljem oli tal erapraksis, ja siis ta juba tutvus Kalniņšiga [teise omanikuga] ja hakkas maja ehitama. Isal oli kusagil 30 või 40000 hüpoteegivõlga. Ta lootis, et tasapisi, sest tal oli oma advokaadi praksis, et ta teenib tagasi ja kustutab võla.

Omanike naised kannavad selle aja traditsioonide kohaselt hoolt kodu eest, kuigi enne abielu olid nad omandanud hea hariduse ja olnud palgatööl - üks oli olnud õpetaja, teine oli aga töötanud ringkonnakohtus masinakirjutajana. Need perekonnad on esimese põlve riialased.

Intervjuude analüüsist järeldub, et majaomanike pered olid 20. sajandi kolmekümnendail aastail stabiilses olukorras: kuigi hüpoteegilaenude abil, oli maja siiski valmis ehitatud, lapsed õppisid prestiižses koolis (Riia Prantsuse lütseumis), Valda kavatses kooli lõpetamise järel suunduda edasi õppima konservatooriumi. Tookordsete laste, praeguste majaomanike mälestustes on maja sellest perioodist rekonstrueeritud kui endine ja idealiseeritud kodu ehk päikesepaistelise lapsepõlve maja. Valda meenutab: 
Meie kolisime siia 1936. aastal. Siin oli suurepärane õu, mitte selline nagu praegu. Veel oli siin liuväli [---] meil olid väga head suhted kõikide meie naabritega [---] need olid erinevast rahvusest - sakslased, juudid, venelased, poolakad. Meie isa oli selgelt pereinimene. Tal oli hea hääl ja sageli ta laulis meile. Ja siis me laulsime koos. Ja pühapäeviti läksime jalutama Mežaparki.

Järgmisena meenutatakse maja kui kaotatud ehk väevõimuga ära võetud kodu ja kolmandaks on see maja, kuhu nüüd sai võimalikuks tagasi pöörduda.

Baltisakslaste repatrieerumine Saksamaale on esimene väliste poliitiliste jõudude algatatud migratsioon. Vaadeldavast majast lahkus neli baltisaksa perekonda. Valda mälestused sellest on järgmised:

Meil siin oli sakslaste lapsi, nende pered hiljem repatrieerusid. Oli Kahlert, neil oli peeglivabrik. Tal oli poeg Gerd. Ja oli selline väike poisike, kaks kolm aastat vana, selline Hans. Kuna me mõlemad rääkisime ühel tasemel saksa keelt, siis ma ei häbenenud temaga rääkida. Ja viiendas korteris oli Helmut ja Kurt, need kah sõitsid minema. Veel oli sakslaste peresid. Nad kõik sõitsid minema. Noh, seejärel oli ka teisi ü̈̈rnikke, seega meie maja oli suhteliselt hea.

Repatrieerumise fakti mäletavad veel kaks maja kauaaegsetest elanikest, viidates, et nende pered tulid elama baltisakslastest mahajäetud korteritesse.

See on esimene suurem migratsioonist põhjustatud muutus majas ja ühtlasi ka Lätis. See on edasiste suurte muutuste eelmäng. Majaelanikud jutustavad intervjuudes, et tollel ajal levis arvamus, et need olulised muutused Lätit ei puuduta. Täiskasvanute vestlustes oli küll tunda teatud muret, kuid inimesed polnud valmis poliitilisteks muutusteks ja repressioonideks, mis eeltoodud sündmustele kohe-kohe järgnesid. Laima mainib jutustuses episoodi lapsepõlvemälestustest:

Seal oli üks onu, minu isa sõber... Ta kadus okupatsiooni esimeste tundide jooksul. Ta ei ilmunud enam kunagi meie koju, ta lihtsat kadus jäljetult. Nii algas see aeg. See hirmutas mind väga.

Mõlemad jutustajad elavad läbi omandatud, vanematelt ülevõetud ja sotsiaalselt toimiva süsteemi hävitamise. Selle süsteemi, milles nad olid sündinud, omandanud hariduse, mille väärtusi olid nad aktsepteerinud. Muutused süsteemis ilmnevad repressioonides. Muutuste tegelikku algust tähistab aga baltisakslaste väljaränne oma etnilisele kodumaale. 


\section{Sundmigratsioon: küüditamine ja kaotatud kodumaja}

1940. aastate algus on piirjooneks, mis eraldab päikselist lapsepõlve edasisest elust. Nõukogude võim toob kaasa konflikte, perede hävitamisi, kodunt väljaajamisi. Uus võim teostab end, lõhkudes senist stabiilset tegelikkust, sh kodu humaanset olemust.

Nõukogude okupatsiooni esimestel kuudel (1940. aasta juuni-juuli) küüditati Balti riikidest umbes 100000 inimest (sealhulgas rahvuslikud vähemused) Nõukogude Liidu kaugetesse regioonidesse (vt lisa 1; Budryte 2003). Mälestused sunniviisilisest migratsioonist on endiselt aktuaalsed elulugudes ja ühtlasi on see oluline ka akadeemilises uurimistöös. Vaadeldava maja mõlema omaniku pered küüditati. Maja muutus nende laste silmis kaotatud omandiks, kaotatud ideaalseks minevikuks. Mõlemad majaomanikud hukkusid võimu käe läbi: üks neist tapeti nõukogude võimu esimestel päevadel, teine suri asumise teisel aastal Siberis.

Laima lugu:

Minu isa oli advokaat, vannutatud advokaat, ja talle kuulus see maja. Ja need, kellele midagi kuulus, olid sotsialismi vaenlased. Ma olin üheksakümnendatel [aastatel] siseministeeriumis mitu korda ja sain vaadata kõiki neid dokumente ja akte, ja põhjendusi. Põhjendus - sotsiaalselt ohtlik element. "Element", sest sellal ei olnud inimesed, vaid elemendid. See sõnastus läheb selle alla, et talle kuulus midagi.

Neljakümne esimese aasta juunis... ma mäletan, ma ärkasin, ma olin just kümneaastaseks saanud ... mingi lärm oli, hirmus kell uksel, ma kuulsin, et miski seal käib mürinal üleval, Kalniņš [teise omaniku pere] elas üleval. Siis ma kuulsin, et koridoris toimub midagi hirmsat, mehed seal rääkisid vene keelt ... ja siis ma kuulsin, et ema ütleb, et see laps on haige. Ega ma ju olnudki nii haige, aga mind pisteti vanaema voodisse ja kaeti kinni. Mind ei lastud enam välja. Ja tuli välja, et need võtjad juhtusid sellised olema, et olid nõus lapse maha jätma. See on harv juhus, see on harv juhus.

Laima vanemad olid asumisel mõned aastad koos, siis isa suri. Laima oletab, et isa surma põhjuseks ei olnud mitte ainult toidupuudus ja rasked elutingimused, vaid eelkõige jäi ta moraalselt alla repressioonide ebaseaduslikule loomusele:

Seadus, kohus, õiguslikkus. Ja seda ta ei suutnud oma lollis peas seedida. Noh, kuidas see saab olla? Just nagu on see üsna absurdne! Noh, 
sellises olukorras ära küsi ega rabele, vaid ela. Aga tema varises sisemiselt kokku.

1944. aastal põgenesid paljud Läti pered 1941. aasta repressioonide kordumist kartes Läände, kuid Laima jäi oma vanaemaga koju:

Vanaema oli see, kes ütles, et ta ei sõida kuskile, sest ta peab ootama tütart Siberist koju. Loomulikult teadmata, kus ta on ja kas ta veel elus on.

Kuigi Laimal õnnestus 1941. aastal haiguse tõttu küüditamisest kõrvale hoida, ei olnud tema elu kergem kui laagris olnutel. Tema ema naasis Lätti illegaalselt, s.o põgenes asumiselt. Laima varjas mitu aastat ema oma väikeses toas, kartes uksekella iga helinat. Ema illegaalsest viibimisest ei saanud võimuasutused teada tänu sellele, et samas kommunaalkorteris elavad sugulased seda varjamist ei paljastanud. Laima jutustab, kuidas ta praegugi ärkab öösiti halvast unest, milles nõukogude võimu esindajad tulevad ta emale järele.

1969. aastal legaliseerus Laima ema võõra nime all: ta ostis endale passi ja kirjutas end oma tuppa sisse.

Valda lugu:

Meid küüditati, sest meie isa ju enam kodus ei olnud (isa arreteeriti ja lasti maha mõned päevad pärast okupatsiooni algust). ${ }^{2}$ Ja ema võeti meilt Torņakalnsi jaamas. Meid saadeti üksi, alaealisi lapsi, noorem vend oli kümnene, mina kuusteist ja vanem seitseteist... Minu ema saadeti seejärel Solikamskisse. Majast koguti kokku kõik ja seejärel, noh mis jaamas kes oli... Laima vanemad olid Šksirotava jaamas, meid viidi Torņakalnsi kaubajaama. Ja järgmisel hommikul meid lahutati. Emake veeti laagritesse, ja hiljem ta Vorkutas neljakümne kolmanda aasta 23. oktoobril suri. Näljast olevat surnud. Ja meie, kolm last, olime Siberis.

[---] ja siis mõne aja pärast mind kutsuti, et ema kutsuvat mind ülemise akna ääres. Ja ema kutsus - kandke hoolt Jānise eest! - meie noorema venna eest. Siis hakkasid vagunid liikuma, ma ei tea, kas nende vagun, või meie, mis sõitis minema, ema kattis näo kätega kinni ja hakkas nutma. Ja see oli viimane, enam ma ema ei näinud. Kas see pole jube! Ühe korraliku hoolitseva armastava ema käest võtta ära kõige kallimad, mis temal on - tema kolm last, ja teda ennast ajada orjusse.

Valda ja tema vennad elasid üle kaks küüditamist - 1941. ja 1949. aasta oma. Valda vend mobiliseeriti tööpataljoni ehitama Siberi suuri magistraale, Valda koos noorema vennaga järgnesid talle. Sõja järel Valda koos vendadega “demobi- 
liseerus" tööpataljonist. Esimese küüditamise ajal kirjutasid nad alla dokumendile, milles lubasid, et ei naase Lätti 25 aasta jooksul, kuid pärast passide saamist pöördusid nad ikkagi kodumaale tagasi. Teel nad "kaotasid" passid, mille seerianumbrid viitasid nende kui represseeritud isikute minevikule. Uute passide saamisel esitlesid nad end juba isikutena, kes on "vabatahtlikult astunud tööpataljoni”. See lubas neil küll hiljem tõlgendada oma biograafilisi andmeid, kuid ei kaitsnud 1949. aastal uue küüditamise eest, mille põhjenduseks oli ebaseaduslik tulek Lätti.

Küüditamise teema ilmneb ka mõne teise vastaja loos nii nende enda kui ka pereliikmete kogemusena. Sunniviisiline pagendamine kodunt võõrale maale väga vaestesse oludesse ja perekondade lahutamine on mitte ainult raske trauma, vaid nendel protsessidel on ka edaspidised mõjud - perede stabiilsuse hävitamine, võimetus anda edasi kogutud rahalist, kultuurilist ja sotsiaalset kapitali, oht kaotada sotsiaalset mälu.

Valda loodud pere lagunes. Ta sattus asumisele kahe kuu vanuse lapsega, kelle kasvatas üksi üles. Mees tuli talle küll järele, kuid et seal polnud tööd, sõitis ta Krasnojarskisse, kus lõi uue perekonna.

Valda vennad abiellusid Siberis küüditatud lätlannadega, kuid elu asumisel, kaugel kodumaast jättis oma jälje nende laste etnilise identiteedi kujunemisele, eriti keeleoskusele, mis on üks olulisi identiteedi kandjaid. Vennapoeg rääkis kolmeaastasena, ainult vene keelt. Valda meenutab: Huvitav - isa ja ema lätlased ja ainult läti keeles rä̈̈givad, kuid pisike vastab ainult vene keeles. Pärast seda, kui nad olid Lätti tagasi tulnud ja elanud siin pikemat aega, hakkas laps siiski rääkima ka läti keelt.

Väljasaatmisest kui sunniviisilisest migratsioonist jutustamisel on mõlemas loos kajastusi selle kohta, et see informatsioon oli nõukogude tingimustes viiskümmend aastat olemas vaid suulises vormis, ja sellest räägiti üksnes pere või lähimate sõprade ringis, keda ühendas omavaheline jäägitu usaldus ja kindlate väärtuste süsteem. Privaatne ja avalik ruum olid sel ajal lahutatud raudse eesriidega. Need mälestused sattusid avalikkuse ette alles taasiseseisvumise järel, nagu ka küüditamistega seotud arvandmed.

Seda olukorda iseloomustab Valda järgmiselt:

Ja me tulime tagasi. Vanaema oli meid juba oodanud mitu päeva ja muretsenud. Miilitsas me enam ei rääkinud midagi, me olime juba targemad, me olime juba läbinud, nagu Gorki on kirjutanud romaani Minu ülikoolid, meie need oma elu ülikoolid olime juba läbi käinud. Me juba teadsime, et kõikjal ei pea tõtt rääkima, ja me ka ei rääkinud, et olime kü̈̈ditatud. Me oleme olnud ära, me oleme evakueerunud sõja ajal... ja sõja ajal on surnud minu isa, ja sõja ajal on minu ema surnud, nii see ju 
tegelikult ka oli, eks! Ainult et mis asjaoludel see toimus, seda me rääkinud. Ja me olime Kaug-Idas, ja me ise sõitsime, ja me juba väikese vennaga ise sõitsime. Ja et ise vabatahtlikult astusime tööpataljoni ja aitasime ehitada kommunismi. Ja nü̈̈d me oleme tagasi tulnud ja kaotanud oma dokumendid, ja meil on teatis, et oleme Kaug-Idas olnud.

Meie ei rääkinud võõrastele midagi. Meil olid omad sugulased, need teadsid meist, meil olid omad sõbrad Kaug-Ida ajast, Siberi ajast, kes samuti kõike teadsid, nii et me ei pidanudki sellest palju rääkima. Aga kõik need aastad me ei rääkinud sellest midagi.

Valda kolleegid enamasti ei teadnud, et ta on olnud küüditatud, tõe juhtunu kohta avaldas ta alles 1980. aastate lõpul.

\section{Massiline sisseränne - fragmenteerunud kodu}

Elanike sissevool Balti riikidesse Nõukogude Liidu teistelt aladelt algas juba 1940. aastal, kuid täpsed arvandmed 1940. ja 1941. aasta esimesel poolel tulnute kohta puuduvad. Suurim sisserändelaine algas 1941. aasta suvel pärast etniliste baltlaste ja Balti riikides elavate etniliste vähemuste massilist küüditamist. Lääneliitlaste ja Nõukogude Liidu 1945. aastal allkirjastatud Potsdami leping viis Euroopa 20. sajandi ühe suurima migratsioonilaineni, kus elukohamuutus puudutas rohkem kui 20 miljonit inimest. Sealhulgas viidi tuhandeid eestlasi, leedulasi ja lätlasi sunniviisiliselt Nõukogude Liidu idaaladele.

Sisseränne teistelt Nõukogude Liidu aladelt saavutas oma haripunkti Teise maailmasõja järel. Ajavahemikus 1945-1959 immigreerus Lätti umbes 400000 etnilist venelast ja 100000 teiste rahvuste esindajat. See moodustas umbes $25 \%$ Läti sõjaeelsest elanikkonnast. Samal ajal vähemalt 60470 lätlast küüditati idaaladele. Võrdluseks võib tuua, et, aastail 1945-1953 immigreerus Eestisse üle 21300 mitte-eestlase, moodustades umbes 19\% sõjaeelsest elanike arvust Eestis. Sellel ajavahemikul küüditati Nõukogude Liidu idaaladele umbes 45000 eestlast. Ajavahemikus 1944-1959 tuli Leetu umbes 150000 etnilist venelast, samal ajal umbes 132000 leedulast küüditati (vt lisa 2, vrd lisa 1).

Sõjajärgsetel aastatel asusid massilise sisserände tulemusel vaadeldavasse majja elama sõjaväelased koos suure hulga erineva astme sugulastega ning pered, kes olid evakueerunud Venemaale ja pöördusid nüüd Lätti tagasi. Võõras võim tõi majja teised elanikud ja nendega koos senisest täiesti teistsuguse elustiili ning väärtuste-orientatsiooni, mis olid kujunenud Lätiga võrreldes 
teises poliitilises, majanduslikus ja sotsiaalses süsteemis. Maja täitus kommunaalkorteritega.

Laima meenutab sõjajärgse immigratsiooni kiiret käiku:

Ah, teil oleks huvitav vaadata neid vanu majaraamatuid... Kuidas siia [majja] on voolanud sisse, millised ainult, ah, armsakene, ah, Jumaluke! Ja siis ma mõtlesin, et on täiesti vale selle siin elamise alusel seda kodakondsust anda. Need inimesed, kes siia tulid, need olid sellised, et otsisid paremat elu, neid kutsuti, neid värvati, jah, ükskõik kust. Aga need, kes neljakümne neljandal ja neljakümne viiendal tulid, need NKVD, kõik need spetsosakonnad, need täitsid kõik need tühjad korterid, kust elanikud olid minema sõitnud.

Valda kui ühe majaomaniku säilitatud majaraamatust võib lugeda sissekandeid, mis iseloomustavad inimeste tulekut Riiga. Uued tulijad kirjutati majja sisse ja suhteliselt lühikese aja - aasta, poolteist - järel said nad uue korteri mujal. Majaraamatus fikseeritud rahvused on erinevad: venelased, juudid, marid, ukrainlased, baškiirid, tatarlased, aga samuti lätlased, kes saabusid Venemaalt. Majaraamatu kanded näitavad, et mõnes korteris (mille elanikud elasid seal ka tagastamise järel) on ühte tuppa 5. novembrist 1945 kuni 11. novembrini 1949 sisse kirjutatud mitu Nõukogude armee sõjaväelast. Sarnaseid kandeid võib leida ka teiste korterite kohta, kus ametilahtris on näidatud kas leitnant, rindelt tulnud kapten; NKVD alampolkovnik; sõjaväeametnik naise ja kolme lapsega jms. Majaraamatu sõjajärgse aja (1945-1948) kohta käivate sissekannete vaatlemisel selgub, et peaaegu igasse korterisse on mõnda aega olnud sisse kirjutatud sõjaväelased või julgeolekuteenistustega seotud inimesed. Neid võib leida nii tühjade korterite nimestikust kui ka seal, kus elas teisigi üürilisi. Maja üheksateistkümnest korterist ainult viies ei olnud nõukogude võimu esindajaid ega nende sugulasi. Nendest viiest korterist kaks asuvad keldrikorrusel, üks oli majahoidja korter, ning ühte neist tuli pärast sõda tagasi Nõukogude armees teeninud mees. Mitmes selle maja korteris elas projekti käivitumise ajalgi pärast sõda Riiga tulnud inimesi.

Andrei on sündinud 1929. aastal Sestroretskis Leningradi (Peterburi) lähedal. Ta on rahvuselt venelane. Tema pere elas Leningradis. Vanemate surma järel 1942. aastal pandi ta lastekodusse. Seal oli ta kaks aastat, kuni tädi ta leidis ja viis Moskvasse. Tädimees oli siseministeeriumi ohvitser. See perekond koos Andreiga saabus 1944. aasta lõpul Riiga. Andrei on endine siseministeeriumi ohvitser, praegu pensionär. Ta käib sageli Moskva kõrgemas miilitsakoolis loenguid pidamas. Andrei arvab, et kõige parem ideoloogia ja ilusaim unistus on nõukogude kommunistliku partei ideoloogia. Kuid see ideoloogia ja unistus varises kokku elluviimise käigus. 
Vladimir on sündinud Kaasanis 1918. aastal, ka tema on venelane. Ta oli sõja algusest alates Punaarmees ja tema sõjatee kulges Berliinini. Ta tuli Riiga ja asus kõnesolevasse majja elama 1947. aastal. Intervjuu temaga toimus vene keeles, ta pakkus võimalust kõneleda ka inglise või jaapani keeles.

Maria on sündinud Novgorodi kandis 1922. aastal. Temagi on venelane:

Sõja ajal viisid sakslased meie perekonna Opotškasse. Kui sõda lõppes, jäime keset välja ilma kõigeta. Sõja järel suundusime tööotsinguile, töötasin turbarabas. Aastal 1951 saabus inimene Lätist ja kutsus tööle Lätti raudtee peale. Paljud nii sõitsidki Lätti. Siin kohtusid nad paljude tuttavatega. Mina abiellusin lätlasega, kuid läti keelt nii ära ei õppinudki. Ma tulin esimesena, seejärel kutsusin ka teisi sugulasi.

Nelli on sündinud 1925. aastal Zadonski oblastis Klenovoje külas, Venemaal. Ta töötas Balti sõjaväeringkonnas, nüüd on ta pensionär. Ta elab Riias 1946. aastast alates, vaadeldavas majas aga 1948. aastast. Ta saabus Riiga koos vennaga, kes oli kutsutud Riiga sõjajärgsele ülesehitustööle. Mõne aja möödudes kutsusid nad enda juurde elama ka oma kolm õde.

Lena on sündinud 1931. aastal Omskis ja tema mees Igor 1932. aastal Odessas. Lena tuli Lätti koos oma perega ja hakkas elama selles majas 1944. aastal. Ka tema isa kutsuti Riiga sõjajärgsele ülesehitustööle.

\section{Tagasitulekud ja järjepidevused}

Pärast esimest küüditamist Riiga tagasi pöördununa elas Valda oma kodumaja ühes üüritoas, kuhu oli sisse kirjutatud tema vanaema. Kui vanaema varsti pärast lastelaste tagasitulekut aastal 1947 suri, sai sissekirjutuse vanaema tuppa vanem vend. 1949. aastal Valda ja tema vendade teistkordsel küüditamisel kaotasid nad Riias elamispinna ja õiguse üldse sinna tagasi pöörduda. Lugudes muutub aga sunniviisilise migratsiooni tulemusel maha jäetud (õigemini neilt ära võetud) maja tagasituleku eesmärgiks, rännakute lõpp-punktiks, migratsiooniprotsessi peatumise märgiks. Valda meenutab, kuidas ta 1957. aastal pärast teistkordset asumiselesaatmist Riiga tagasipöördununa jalutas kodumajani:

Oma tagasituleku järel kutsusin ma kaasa oma poja ja ristitütre seda maja vaatama. Meil oli keelatud seal elada. Me tohtisime ainult vaadata seda väljastpoolt. Me tegime tiiru selle ümber ja siis ma ütlesin-see on meie maja. Vaadake ja pidage seda meeles. 
Valda sai siiski õiguse sinna majja tagasi minna pärast varade tagastamist taasiseseisvunud Lätis. Tema mõlemad vennad olid siis juba surnud. 20. jaanuaril 1993. aastal läks Valda tagasi kodumajja elama. Koos Laimaga sõitsid nad enne kodumajja minekut kalmistule Laima ema ja Valda vanaema haudadele. Valda vanaema oli säilitanud maja varasemaid dokumente, kergendades sellega nüüd tunduvalt maja tagasisaamist. Esimese öö veetis Valda majas veel ilma asjadeta, need toodi järele järgmisel päeval. Siis saabusid vennalapsed, joodi šampust, anti intervjuu ajakirjanikule omandi tagasisaamise teemal. Intervjuu põhjal kirjutatud artikkel "Tagasitulek" avaldati Riia suurimas ajalehes. Enam kui viiskümmend aastat kestnud rännakud "majata" ajal olid lõppenud. Valda jutustab:

Hommikuti lähen ma koeraga jalutama. Ja siis ma jalutan ümberringi, ja siis sellel skvääril jalutan ja kõik ... siis ma tunnen end-jah, tõepoolest, ma olen tagasi! Ma tunnen end siin õnnelikuna! Öeldakse, et praegu pole moes öelda, et mul läheb hästi, aga ma tunnen end õnnelikuna. Noh, mul pole halb, mul on hea!

Koos Valdaga asuvad majja elama tema nüüd juba manalas olevate vendade järeltulijad, kes pärivad samuti omandiõiguse osale sellest majast. Valda võtab enda peale majavanema kohustused, sest ta on suurte kogemustega raamatupidaja.

Laima on majaomanike kummastki perest ainus, kes on elanud selles majas kogu aeg, maja ehitamisest tänaseni. Selleks, et sõja järel ei koliks sinna elama sisserändajad, kutsus Laima vanaema enda juurde elama sugulasi, muutes oma eluaseme nii nõukogudeaegseks kommunaalkorteriks. Oma vanemate viietoalisest korterist hõivas Laima ainult ühe väikese toa. Kunagi oli see tema isa töökabinet ja selles toas on isa kabineti mööbel säilinud tänaseni. Selle toaga seonduvad nostalgilised mälestused lapsepõlvest, mistõttu Laima ei soovi elada üheski teises, kuigi ehk mugavamas toas. Ta on korteri teised toad andnud lähedase sõbra perele. Laima distantseerub maja ma-

Foto 4. Maruta Pranka koos Norra kolleegidega uuritava maja juures (maja pildil vasakul). Māra Zirnīte foto 1996.

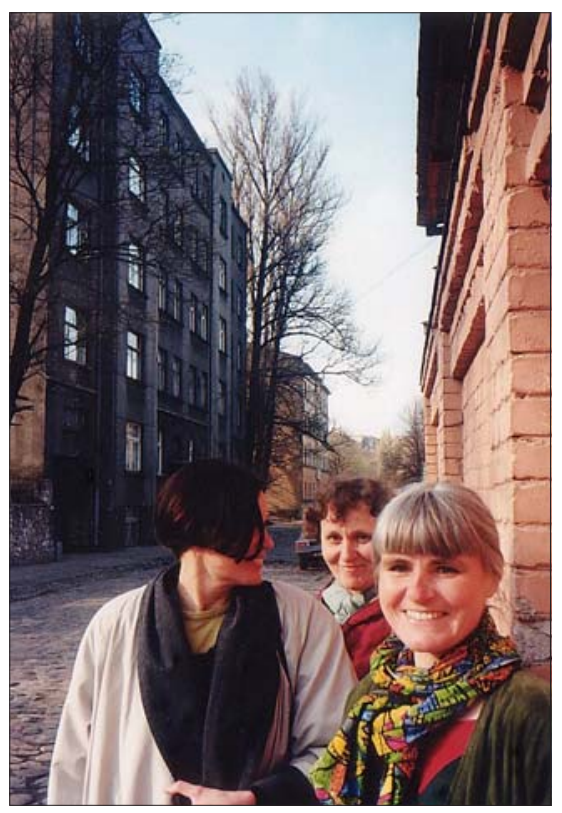


janduslikest probleemidest. Tema töö ja huvid on seotud kirjanduse uurimisega. Ta on olnud osaline mitmes teaduslikus uurimisprojektis ja on mitme teaduspublikatsiooni autor. Kuna tal pole oma perekonda, siis on ta ühe osa oma pärandist müünud, osa pärandanud sõpradele ja sugulastele ning ühe kolmandiku kinkinud Valdale abi eest maja tagasisaamisel ja majandamisel.

Poliitilised ja majanduslikud muutused taasiseseisvunud Lätis tõid kaasa varatagastamise ja erastamisprotsessi, mis omakorda põhjustas uue rände. Needki peegelduvad uuritavas majas. Muutused toimusid peamiselt ajavahemikus 1994-2000. Majast lahkusid need elanikud, kes ei suutnud tasuda kõrget üüri. Nad olid peamiselt vanemad, väikeste sisetulekutega inimesed. Majja tulid pered, kes suutsid maksta korteri eest turuhinda. Ühtlasi kujutavad nad endast uut sotsiaalset rühma: nad on inimesed, kes tulevad sõja ja okupatsiooni põhjustatud pagulusest Lääneriikides tagasi Lätti.

Māris on sündinud Lätis. 1944. aastal põgenes ta oma vanematega välismaale, sattudes alguses Saksamaale, seejärel USA-sse, kus ta elas 1994. aastani, kuni ta otsustas Lätti tagasi tulla. Intervjuus kirjeldab Māris kodumaale tagasipöördumise otsustust järgmiselt:

Üheksakümnendal aastal oli minu proua koos sugulaste ja vanemate lastega laulupeol, sest lapsed laulsid seal kooris. Ja siis, kui ta tuli tagasi, oli tal raske operatsioon. Ja juba enne seda operatsiooni aastal 1991 oli siin Läti teadlaste kongress, millest ma ka osa võtsin. [---] Ja siis pärast seda operatsiooni hakkasime mõtlema, mis ja kuidas - milleks me elame, ja kuidas me tahame elada. Sest lapsed olid suureks kasvatatud, maja oli makstud. Lõppude lõpuks oleme ju seda läti keelt, A ja B, ja C-d lastele ópetanud ja kodus rääkinud. Noh, kui Läti on vaba, peab hakkama vaatama, kuidas on, kas ei peaks tagasi sõitma.

Ühtlasi tunnistab ta, et ta pole siiski päris kindel, kas nad on päriseks tagasi pöördunud, sest Ameerikas elavad kõik nende kolm last koos peredega.

\section{Kokkuvõte}

Uuritavas majas toimunu võimaldab näidata üldisi sotsiaalajaloolisi protsesse Lätis 1930. aastatest alates. Maja loos on jälgitav ühiskonnas toimunud ajalooliste kokkupõrgete ja sotsiaalsete protsesside dünaamika. Maja elanike seas on (või oli) nii represseerituid kui ka repressioonide täideviijaid, erinevast rahvusest, erinevatest vanuserühmadest ja soost erinevaid elukogemusi esindavaid inimesi. Migratsiooniprotsessid on selle maja näitel identifitseeritavad ja neid saab vaadelda lähiplaanis. 
Maja ilmneb uurimuses kui omand, materiaalne väärtus ja finantsressurss, olles tähtis tegur ainelise heaolu tagamisel. Maja tagasisaamine ja sinna tagasipöördumine on ühelt poolt omandi ja peavarju tagasisaamine, teiselt poolt on see aga ka elukäigu katkestuste kokkusõlmimine, turvalisuse, stabiilsuse ja põlvkondade järjekestvuse sümboli tagasisaamine. Maja on vaimne väärtus - õnneliku mineviku, lähedaste inimeste ja mälestuste koondkuju. Tagasitulek majja on tagasitulek eelmiste põlvkondade jäetud ressursside juurde. Maja on siin kui ruumis materialiseerunud aeg. Kui omandi tagasisaamist võib pidada täielikuks ja lõpetatuks, siis sümboolne tagasisaamine pole absoluutne, sest vähemalt kaks põlvkonda on sellest füüsiliselt lahus olnud, intervjueeritavate sugulased on kannatanud poliitilist vägivalda ja osalt selles hukkunud.

Käesolevas uurimuses on elulood nagu elulood üldse jutustaja valikud ajaloolistest ja sotsiaalsetest protsessidest. Valikulisuse ja katkendlikkuse aluseks on nii ajast ja unustamisest tulenevad tegurid kui ka intervjueeritavate enesetsensuur. Nimetatud filtrid tavatsevad olla ka muutlikud ja dünaamilised. Selles oli võimalik veenduda käesoleva uurimistöö käigus, intervjueerides samu inimesi mitu korda. Siiski annab elulugudes väljendatud kogemus (mis on olnud ühenduses teiste kogemustega ja on seega oma loomult sotsiaalne) informatsiooni jutustaja kohast sotsiaalsetes protsessides ja sotsiaalse konteksti mõjust inimese elukäigule.

Tõlkinud Valts Ernštreits

\section{Kommentaarid}

1 Migratsiooniprotsesside iseloomustamiseks on artiklis kasutatud majaelanike elulugudes sisalduvat teavet. Kõige põhjalikumalt on analüüsitud aga maja kahe omaniku eluloointervjuusid ning tsitaadid pärinevad just neist lugudest. Et säilitada jutustajate suhtelist anonüümsust, kasutatakse artiklis varjunimesid.

${ }^{2}$ Valda isa oli Poliittalituse uurimisosakonna juhataja - autori märkus.

\section{Kirjandus}

Budryté, Dovilé 2003. Today's Politics and Yesterday's Embitterments: Ethnic Restructuring and its Aftermath in The Baltic States. Münz, Rainer \& Ohliger, Rainer (toim). Diasporas and Ethnic Migrants: Germany, Israel, and Post-Soviet Successor States in Comparative Perspective. London: Frank Cass Publishers, lk 206-220.

Hammersley, Martyn 1990. The dilemma of qualitative method: Herbert Blumer and the Chicago tradition. London: Routledge. 
Lauristin, Marju 2004. Lives and Ideologies: A Sociologist's View on the Life Stories of Two Female Tractor-Drivers. Kirss, Tiina \& Kõresaar, Ene \& Lauristin, Marju (toim). She Who Remembers Survives, Interpreting Estonian Women's Post-Soviet Life Stories. Tartu: Tartu University Press, lk 178-202.

\section{Lisa 1}

Nõukogude võimu poolt Balti riikidest küüditatute arv aastail 1940-1953 (ligikaudsed andmed \%) (Budryté 2003: 209)

\begin{tabular}{|c|c|c|c|}
\hline & $\begin{array}{l}\text { Küüditatute arv } \\
\text { 1940-1941 }\end{array}$ & $\begin{array}{l}\text { Küüditatute arv } \\
\text { 1945-1949 }\end{array}$ & $\begin{array}{l}\text { Küüditatute arv } \\
\text { kokku: } \\
\text { 1939-41, 1944-1953 }\end{array}$ \\
\hline $\begin{array}{l}\text { Eesti, } 1934 \\
\text { Elanike koguarv } \\
\mathbf{1} \mathbf{1 2 6 0 0 0}\end{array}$ & Umb 10605 & $20702(25.03 .1949)$ & umb 40455 \\
\hline $\begin{array}{l}\text { Läti, } 1935 \\
\text { Elanike koguarv } \\
1905000\end{array}$ & Umb 16563 & $\begin{array}{l}43904 \\
41708 \\
(25 .-30.03 .1949)\end{array}$ & umb 60469 \\
\hline $\begin{array}{l}\text { Leedu, } 1923 \\
\text { Elanike koguarv } \\
\mathbf{2} \mathbf{6 2 0} 000\end{array}$ & Umb 26000 & $\begin{array}{l}86654 \\
41000 \\
(22 .-27.03 .1949)\end{array}$ & umb 132000 \\
\hline
\end{tabular}

\section{Lisa 2}

Elanike arvu etnilise koosseisu muutused Balti riikides (\%) sunniviisilise migratsiooni (küüditamise) ja massilise väljarände tulemusel (Budryté 2003: 208).

$\begin{array}{lrrrr}\text { Eesti } & \mathbf{1 9 3 4} & \mathbf{1 9 5 9} & \mathbf{1 9 8 9} & \mathbf{1 9 9 0 - 1 9 9 9} \\ \text { Eestlased } & 88,2 & 74,6 & 61,5 & 65,2 \\ \text { Venelased } & 8,2 & 20,1 & 30,3 & 28,09 \\ \text { Sakslased } & 1,5 & 0,1 & 0,2 & 0,09 \\ \text { Juudid } & 0,4 & 0,5 & 0,3 & 0,16 \\ \text { Muud } & 1,7 & 4,7 & 7,7 & 6,46 \\ \text { Elanike arv } & 1126000 & 1197000 & 1566000 & 1445000\end{array}$




\begin{tabular}{|c|c|c|c|c|}
\hline Läti & 1935 & 1959 & 1989 & 1999 \\
\hline Lätlased & 77,0 & 62,0 & 52,0 & 55,7 \\
\hline Venelased & 8,8 & 26,6 & 34,0 & 32,3 \\
\hline Juudid & 4,9 & 1,7 & 0,9 & 0,4 \\
\hline Sakslased & 3,3 & 0,1 & 0,1 & 0,1 \\
\hline Muud & 6,0 & 9,6 & 13,0 & 11,5 \\
\hline Elanike arv & 1905000 & 2094000 & 2667000 & 2439000 \\
\hline Leedu & 1923 & 1959 & 1989 & 1998 \\
\hline Leedulased & 83,88 & 79,3 & 79,6 & 82,3 \\
\hline Venelased & 2,49 & 8,5 & 9,4 & 8,2 \\
\hline Juudid & 7,58 & 0,9 & 0,3 & 0,2 \\
\hline Poolakad & 3,23 & 8,5 & 7,0 & 6,8 \\
\hline Muud & 2,82 & 2,8 & 3,7 & 2,5 \\
\hline Elanike arv & 2620000 & 2711000 & 3675000 & 3653000 \\
\hline
\end{tabular}

\section{Summary}

\section{Migration - The Opposite of Home}

\section{Maruta Pranka}

Key words: biographical method, life history research, longitudinal analysis, migration

The article introduces the possibilities of using the biographical method for researching the processes of migration on the basis of analysing the materials of the research project Māja ('Home/House').

Migration, the movement of people from one location to another, farther or nearer, brings along the change of home. While one's home is the symbol of stability, migration can be described as being the opposite of stability. Oral history researchers from the Institute of Philosophy and Sociology of the University of Latvia have continuously worked on the Māja project since its launch in 1995. They have repeatedly interviewed the residents of an apartment house in Riga and consulted their personal documents. The information collected in the course of the study deals with the period from the year 1936 (when the house was built) to the present day. The study approaches the life stories of the inhabitants as subjective social reconstructions of the past, which are interpreted in the context of the observed residential house and recent history of Latvia. The dynamics of historical conflicts and social processes that took place in the society can be traced in the history of the house. Upon the analogy of this house, migration processes can be identified and viewed in close-up.

On the one hand, the house is characterised in this study as an actual property, material value and financial resource, and an important factor for securing material 
well-being. On the other hand, however, the regaining of and return to the house is seen as something that binds together the disrupted pieces of life and reemerges as the symbol of safety, stability, and the continuity of generations. The house is a spiritual value, an epitome of the past happiness, close people, and memories. 